\title{
Antimicrobial effect of smoking milk handling containers' inner surfaces as a preservation method in pastoral systems in Kenya
}

Nobert Wafula Wanjala, Joseph Wafula Matofari and John Masani Nduko*

\begin{abstract}
Pastoral communities in Kenya have used smoke from specific herbs as a technique of disinfecting milk-handling containers, preserving milk and to impart a characteristic desired flavour to raw camel milk. The smoking is expected to extend the shelf life of the camel milk, despite the high environmental temperatures $\left(>28^{\circ} \mathrm{C}\right)$. The aim of this study was to determine the antimicrobial effect of smoke on plastic milk-handling container surfaces and determine the efficacy of smoking as a preservation method. Smoked plastic milk-handling containers $(n=25)$ were conveniently collected from pastoral community households in Isiolo County, Kenya. Two containers were prepared by either washing and rinsing using hot water to be the negative control or rinsing and disinfecting using a chlorine-based agent to be the positive control. The inner surfaces of the containers were aseptically swabbed and analysed for total viable count (TVC), total coliform count (TCC), and lactic acid bacteria (LAB). The TVC from the smoked containers was $4.64 \pm 0.43 \log _{10} \mathrm{cfu} / \mathrm{cm}^{2}$ while the TCC was $4.00 \pm 0.66 \log _{10} \mathrm{cfu} / \mathrm{cm}^{2}$ and the LAB were 3 . $75 \pm 0.59 \log _{10} \mathrm{cfu} / \mathrm{cm}^{2}$, and those of the negative control (plain-water-washed non-smoked plastic container) were $5.99 \pm 1.03,5.07 \pm 0.91$, and $4.81 \pm 0.81 \log _{10} \mathrm{cfu} / \mathrm{cm}^{2}$ for TVC, TCC, and $L A B$, respectively. The mean microbial load of milk bulked in smoked containers was $5.10 \pm 0.96,3.61 \pm 2.13$, and $3.84 \pm 2.22 \log _{10} \mathrm{cfu} / \mathrm{ml}$ for TVC, TCC, and LAB, respectively, while the mean microbial load of milk bulked in chlorine-disinfected containers was $5.23 \pm 1.11,2.46 \pm$ 2.18 , and $2.04 \pm 1.35 \log _{10} \mathrm{cfu} / \mathrm{ml}$ for TVC, TCC, and LAB, respectively. The common types of microbes were Gramnegative rods (57.3\%), Gram-positive rods (25.5\%), and Gram-positive cocci (17.2\%). The most prevalent coliforms from all types of the containers and milk were Escherichia coli spp. and Enterobacter spp. while the LAB were Lactobacillus spp. and Lactococcus spp. Therefore, smoking of milk-handling containers can be recommended as an effective method for disinfection of milk-handling containers and as a method of preservation of camel milk in the arid and semi-arid areas of Kenya, where the cold chain or processing infrastructure is poor.
\end{abstract}

Keywords: Camel milk preservation, Pastoral communities, Smoked milk container, Isiolo County

\section{Background}

Camel milk production in Kenya is estimated at 937,000 tonnes in 2013, valued at about 11 billion Kenyan shillings (108 million US Dollars) (FAO 2016). This quantity of milk represents about $19 \%$ of the national Kenyan milk production (FAO 2016). Therefore, camel milk contributes to food security and economic livelihoods of communities in the arid and semi-arid lands (ASAL) in

\footnotetext{
* Correspondence: ikobausy@gmail.com

Department of Dairy \& Food Science \& Technology, Egerton University, P.O Box 536-20115, Egerton, Kenya
}

\section{Springer Open}

(c) 2016 The Author(s). Open Access This article is distributed under the terms of the Creative Commons Attribution 4.0 International License (http://creativecommons.org/licenses/by/4.0/), which permits unrestricted use, distribution, and reproduction in any medium, provided you give appropriate credit to the original author(s) and the source, provide a link to the Creative Commons license, and indicate if changes were made.

Kenya (Wayua et al. 2012). It is estimated that $55 \%$ of the total camel milk produced in Kenya is marketed, $35 \%$ is for household use, and $10 \%$ is consumed by the calf (Muriuki 2011). Analysis of current camel milk value chain indicates that only $12 \%$ of the milk is marketed, the bulk of which is sold in raw form to rural consumers $(10 \%)$, and only $2 \%$ reaches urban consumers. Of the remaining milk ( $88 \%$ ) that does not reach the market, $38 \%$ is directly used by camel-keeping households and their herders as part of their food requirements and the remaining $50 \%$ goes to waste (Musinga et al. 2008). 
Milk post-harvest loss is the measured qualitative and quantitative losses along the dairy value chain (Hodges et al. 2011). Quantitative milk loss is measured as the reduction in its weight or volume due to spillage and forced consumption. Forced milk consumption occurs mostly in areas with surplus, and the family uses the milk or it is given to the calves or neighbours. On the other hand, qualitative milk losses occur due to physical and microbial spoilage as a result of contamination (Muriuki 2003; Buzby and Hyman 2012). Most often, milk is contaminated during milking, handling, and transportation. Milk is a good growth medium for many micro-organisms because of its high water content, nearly neutral $\mathrm{pH}$, and variety of available essential nutrients. This is more pronounced since Kenya lies in the tropics where temperatures are ideal for quick deterioration of milk quality and safety (Godefay and Molla 2000).

Milk from healthy animals is sterile, however; postharvest handling practices are the major sources of microbial contamination of raw milk (Coorevits et al. 2008). Contamination of milk at farm level to collection centres could be attributed to handling of milk with unclean equipment, use of poor-quality water for cleaning, and the use of ineffective and inappropriate sanitation agents (Muriuki 2011; Yilma 2012). All milk-handling equipment/utensils must be effectively cleaned and disinfected so as to reduce the levels of microbial contamination. Cleaning is the most important part of the sanitation process, and if milking equipment/utensils are not kept physically clean, chemicals and other disinfectants are likely to be ineffective (Saran 1995).

Pastoralists in Kenya use plastic containers, 'jerry cans', for handling camel milk. Most often, the containers are fumigated by smoke as a means of disinfection after cleaning (Wayua et al. 2012). This traditional practice is done to increase the shelf life of milk and to add a characteristic desired smoky flavour to the milk (Melesse 2013). Studies have indicated that smoke treatment lowers the microbial load on the inner surface of milkhandling containers (Mogessie and Fekadu 1993), hence resulting in the preservation of camel milk (Tezera and Bruckner 2000). This traditional technology is known locally by the Isiolo County pastoral communities in Kenya as qorasum. The fumigation of the milk-handling containers is accomplished by smoke from smouldering wood of specific tree species, which includes Olea africana, Acacia nilotica, Balanites aegyptiaca, and the Combretum spp. (Wayua et al. 2012). During smoking, the containers are inverted over hot smouldering chips until the smoke stops coming out of the container. Then the residual charcoal pieces are brushed in the containers with special twigs. Wood smoke is known to contain over 400 antimicrobial compounds. These compounds include acids, alcohols, carbonyls, esters, furans, lactones, and phenols. The compounds in wood smoke originate from the polymers in the wood and the heat-induced chemical reaction between the heated polymers, gasified intermediates, and moisture (Toledo 2008). Most of the compounds in smoke are natural antimicrobials and are responsible for the preservative effect on milk and milk products and for the improved organoleptic properties of smoke-treated products (Omar and Ahmed 2012).

The practice of smoking of milk-handling plastic containers in the camel milk value chain is strongly believed to extend the shelf life of the raw camel milk. However, there is no information on the efficacy of the smoking process on the reduction of the microbial load on the inner surface of the plastic milk-handling containers. The objective of this study was to determine the microbial load on smoke-treated milk-handling plastic containers and the effectiveness of the smoking technique as a preservation method of camel milk.

\section{Material and methods}

\section{a. Study area}

The study was carried out in Isiolo County, located in eastern Kenya, about $285 \mathrm{~km}$ north of Nairobi. The County is located at coordinates $0^{\circ} 21^{\prime} 0^{\prime \prime}$ north and $37^{\circ}$ $35^{\prime} 0^{\prime \prime}$ east and an altitude ranging from 200 to $300 \mathrm{~m}$ above sea level (ASL) although there are some areas in the County that go up to 1,000 ASL. Its annual average temperature ranges between 12 and $28{ }^{\circ} \mathrm{C}$ and receives low rainfall ranging between 300 and $500 \mathrm{~mm}$ per year.

\section{b. Sample collection}

A total of 25 freshly smoked plastic milk-handling containers were conveniently collected from different camel pastoralists $(n=13)$ in Isiolo County, Kenya, during milk-harvesting time. The containers were transported to the laboratory under aseptic conditions until analysed for microbial load. Control containers were prepared in the laboratory as follows: the positive control containers (3) were the non-smoked plastic milk containers prepared by rinsing and disinfecting with Duet $^{\oplus}$, a chlorine-based disinfectant, at a recommended concentration of $300 \mathrm{ppm}$, and the second control containers (3) were the non-smoked plastic milk containers prepared by rinsing and not treated by chlorine or smoked. Sterile swabs were pre-wetted by peptone water and used to swab $25 \mathrm{~cm}^{2}$ of inner surfaces (of the smoked, non-smoked and chlorine-treated, and nonsmoked and non-chlorine-treated plastic milk-handling containers in triplicates). Sampling of the surfaces was done by rotating the cotton swab end on the designated container surfaces. The cotton swabs were then transferred 
into $9 \mathrm{ml}$ of $0.1 \%(w / v)$ buffered peptone water and shaken using a vortex for $2 \mathrm{~min}$ to dislodge micro-organisms.

In addition, a total of 18 milk samples were collected aseptically from camel herds before ( 9 samples) and after (9 samples) bulking of the harvested milk in smoked, non-smoked and chlorine-treated, and non-smoked and non-chlorine-treated containers. During camel milk sample collection, approximately $300 \mathrm{ml}$ of raw milk samples were aseptically collected and placed into sterile bottles. Subsequently, the samples were put into iceboxcontaining ice packs and then transported to the Department of Dairy and Food Science and Technology laboratories, Egerton University, and Isiolo referral hospital microbiology laboratory for microbial analysis.

\section{c. Microbial analysis}

The swabs from surfaces of milk-handling containers and milk samples were analysed for total viable count (TVC), total coliform count (TCC), and lactic acid bacteria (LAB) count using appropriate sterilized media. The samples were appropriately serially diluted in buffered peptone water before analysis.

\section{Total viable count}

Milk-handling container surface swabs and milk samples were pour-plated on plate count agar (PCA) (Oxoid, UK) and incubated at $37{ }^{\circ} \mathrm{C}$ for $48 \mathrm{~h}$. Finally, the colonycounting was done using Dr. N. Gerber digital colony counter (Schneider and Co., Zurich) and the counts recorded.

\section{Total coliform count (TCC)}

Appropriate triplicate serial dilution of milk-handling container surface swabs and milk samples were pourplated on Violet Red Bile Agar (Oxoid, UK) and incubated at $37{ }^{\circ} \mathrm{C}$ for $24 \mathrm{~h}$, and typical dark red colonies on the plates were considered as coliforms and counted.

\section{Lactic acid bacteria}

Samples of milk-handling container surface swabs and milk were serially diluted following similar methods as for total viable count, but appropriate dilutions were pour-plated on MRS agar (Oxoid, UK) then incubated at $37^{\circ} \mathrm{C}$ for $48 \mathrm{~h}$ and typical LAB counted. The LAB isolates were further examined by their ability to grow at 15,35 , and $45{ }^{\circ} \mathrm{C}$ for 5 days and in 2, 4, and $6.5 \%$ strength sodium chloride $(\mathrm{NaCl})$ in MRS broth. The growth of LAB isolates at different temperatures and salt concentrations was visually confirmed by turbidity changes in the MRS broth after 24, 48, and $72 \mathrm{~h}$ (Azadnia and Khan 2009).

\section{Identification of typical isolates}

The typical colonies were further isolated and identified according to their morphological, physiological, and biochemical characteristics. The tests carried out were Gram reaction test, catalase test, oxidase test, and methyl-red (MR) test, Voges-Proskauer (VP) test, indole test, and sugar fermentations. The sugars used for testing of the fermentation of the isolates were sucrose, galactose, glucose, lactose, and mannitol (Grainger et al. 2001).

\section{d. Statistical analysis}

Data on microbial counts (TVC, TCC, and LAB) were first transformed to logarithmic values $\left(\log _{10}\right)$ of colonyforming units per $\mathrm{cm}^{2} / \mathrm{ml}\left(\mathrm{cfu} / \mathrm{cm}^{2}\right.$ or $\left.\mathrm{ml}\right)$ before statistical analysis. The means of the transformed microbiological values for smoked, non-smoked and chlorine-treated, and non-smoked and not-treated containers and milk samples were analysed for analysis of variance (ANOVA) using General Linear Model (GLM) procedure of SAS version 9.1 (SAS Institute Inc. 2006). Mean separations were done using Least Significant Difference (LSD) at $P \leq 0.05$.

\section{Results and discussion}

Microbial load of smoked and non-smoked milk container surfaces

The mean microbial loads for smoked and chlorinedisinfected milk container surfaces were significantly lower than those on plain-water-washed non-treated plastic containers (Table 1). However, chlorine-disinfected milk container surfaces had low mean total viable bacterial count (TVC), TCC, and LAB than smoked container surfaces. There were significant differences $(P<0.05)$ in the microbial load between smoked surfaces and the chlorinedisinfected surfaces for TVC, TCC, and LAB (Table 1), indicating that smoking had an effect of reducing the microbial load on the surfaces just like chlorine disinfection. Milk-handling containers are a major source of microbial contamination in milk if not adequately cleaned and disinfected (Lore et al. 2006).

The mean microbial load (TVC, TCC, and LAB) in harvested milk before bulking were lower than the microbial load in milk after bulking in the smoked, chlorinedisinfected, and plain-water-washed containers (Table 2). Milk bulked in smoked containers had significantly lower microbial loads compared to the milk bulked in plainwater-washed containers, a demonstration of the antimicrobial effect of smoking. Therefore, the microbial load on milk-handling containers during milk-bulking has a consequence on the microbial load of bulked milk as a result of contamination from the container inner surfaces. The increase in the microbial load in milk after bulking in comparison to microbial load before bulking could also be 
Table 1 Microbial loads of surface of smoked, chlorine-disinfected, and plain-water-washed non-treated milk-handling plastic containers

\begin{tabular}{lccc}
\hline Microbial load/sample & $\begin{array}{l}\text { Smoked containers } \\
\left(\log _{10} \mathrm{cfu} / \mathrm{cm}^{2}\right)\end{array}$ & $\begin{array}{l}\text { Chlorine-disinfected container } \\
\left(\log _{10} \mathrm{cfu} / \mathrm{cm}^{2}\right)\end{array}$ & $\begin{array}{l}\text { Plain-water-washed non-treated plastic container } \\
\left(\log _{10} \mathrm{cfu} / \mathrm{cm}^{2}\right)\end{array}$ \\
\hline TVC & $4.64 \pm 0.43^{\mathrm{a}}$ & $3.47 \pm 0.06^{\mathrm{b}}$ & $5.99 \pm 1.03^{\mathrm{c}}$ \\
TCC & $4.00 \pm 0.66^{\mathrm{a}}$ & $2.55 \pm 0.02^{\mathrm{b}}$ & $5.07 \pm 0.91^{\mathrm{c}}$ \\
LAB & $3.75 \pm 0.59^{\mathrm{a}}$ & $0.89 \pm 0.24^{\mathrm{b}}$ & $4.81 \pm 0.81^{\mathrm{c}}$ \\
\hline
\end{tabular}

The values are means \pm standard deviations of three replicates from each container. Means with the same letter (for each row) are not statistically different

attributed to the contamination from the milk handlers (Odongo et al. 2016).

The microbial loads in the bulked milk were nearly similar to the microbial load on the container surface and higher than in milk before bulking, indicating contamination of milk from the container inner surfaces. Therefore, the act of bulking and re-bulking of milk into several containers from the bulking at the herd level through several stages/points along the chain to the market creates or increases risks of microbial contamination from the inner surface of containers. Studies have shown that there are increases of microbial load in camel milk from the herd level to the primary collection centres and final market due to the practice of transferring milk between several containers (Kaindi et al. 2011).

\section{Characteristics of the predominant microbial isolates Prevalence of predominant isolates based on physiological and Gram-staining test}

Gram-negative rods (GNR) were the predominant micro-organisms $(51.6 \%)$ in bulked milk and on the surfaces of milk-handling containers (both smoked and non-smoked) rather than Gram-positive rods (GPR) $(32.8 \%)$ in bulked milk and on the surfaces of milkhandling containers and Gram-positive cocci (Table 3). The percentage prevalence of GNR from chlorinedisinfected milk container surfaces $(72.2 \%)$ was higher than the prevalence of GNR from surfaces of the smoked milk-handling container $(57.3 \%)$ and bulked milk (51.6 \%). It was also found out that smoked milkhandling container surfaces had higher prevalence of Gram-positive cocci (GPC) (17.2 \%) and GPR (25.5\%) than chlorine-disinfected surfaces (10.4 and $15.6 \%$, respectively) (Table 3).

Studies have shown that innate resistance especially in Gram-negative bacteria, due to the complexity of their cell wall, which is a double-membrane structure, offers a higher level of resistance to antibacterial agents than that in Gram-positive bacteria (Russell and Chopra 1996). The outer membrane of Gramnegative bacteria acts as a barrier that limits the entry of antibacterial compounds, which is a chromosomally controlled property of the bacterial cell (McDonnell and Russell 1999). This could be one of the reasons why there were more GNR than GPC and GPR combined from the isolates from milk bulked in smoked containers, chlorine-disinfected container surfaces, and smoked container surfaces (Table 3). It can therefore be deduced that GNR may be resistant to the antimicrobial components in the smoke more than GPC and GPR. The higher prevalence of GNR in the chlorine-disinfected milk container surface as compared to the smoked container surface could also be due to their higher resistance to chlorine-based disinfectants than smoke antibacterial compounds. Hence, this indicated that smoke is a better disinfectant against GNR than chlorine-based sanitizers. Resistance has also been reported to be acquired as a result of genetic changes resulting from acquisition of plasmids and transposon-encoding resistance proteins. Plasmidmediated resistance is unlikely to occur in Gramnegative bacteria (McDonnell and Russell 1999). This could be the cause of the Gram-positive bacteria's recalcitrance to smoke and chlorine treatments on the surface of milk-handling containers. Smoked containers had higher Gram-positive bacteria load compared to chlorine-disinfected container surfaces. This could be Gram-positive bacteria on these surfaces acquiring resistance to compounds in the smoke. When comparing, chlorine disinfection had superior effects on the reduction of Gram-positive bacteria than smoke treatment, possibly due to the high oxidizing activity of chlorine that destroys cells (Bloomfield 1996).

Table 2 The microbial load of milk before bulking and from the different containers of bulking

\begin{tabular}{lcccc}
\hline $\begin{array}{l}\text { Microbial type/ } \\
\text { sample type }\end{array}$ & $\begin{array}{l}\text { Milk before bulking } \\
\left(\log _{10} \mathrm{cfu} / \mathrm{ml}\right)\end{array}$ & $\begin{array}{l}\text { Milk bulked in smoked } \\
\text { containers }\left(\log _{10} \mathrm{cfu} / \mathrm{ml}\right)\end{array}$ & $\begin{array}{l}\text { Milk bulked in chlorine-disinfected } \\
\text { containers }\left(\log _{10} \mathrm{cfu} / \mathrm{ml}\right)\end{array}$ & $\begin{array}{c}\text { Milk bulked in plain-water-washed } \\
\text { containers }\left(\log _{10} \mathrm{cfu} / \mathrm{ml}\right)\end{array}$ \\
\hline TVC & $4.73 \pm 0.71^{\mathrm{a}}$ & $5.10 \pm 0.96^{\mathrm{b}}$ & $5.23 \pm 1.11^{\mathrm{b}}$ & $6.22 \pm 2.47^{\mathrm{c}}$ \\
TCC & $0.75 \pm 1.33^{\mathrm{a}}$ & $3.61 \pm 2.13^{\mathrm{b}}$ & $2.46 \pm 2.18^{\mathrm{c}}$ & $4.41 \pm 2.01^{\mathrm{d}}$ \\
LAB & $1.36 \pm 1.89^{\mathrm{a}}$ & $3.84 \pm 2.22^{\mathrm{b}}$ & $2.04 \pm 1.35^{\mathrm{c}}$ & $3.93 \pm 1.14^{\mathrm{b}}$ \\
\hline
\end{tabular}

The values are means \pm standard deviations of three replicates from each container. Means with the same letter (for each row) are not statistically different 
Table 3 Comparison of prevalence of isolates based on the physiological characteristics and Gram-staining

\begin{tabular}{lccc}
\hline Incidence of isolates & Chlorine-disinfected container (isolates $n=17)$ & Smoked containers (isolates $n=58)$ & Bulked milk (isolates = 36) \\
\hline Gram-positive cocci (\%) & 10.4 & 17.2 & 15.6 \\
Gram-positive rods (\%) & 15.6 & 25.5 & 32.8 \\
Gram-negative rods (\%) & 72.2 & 57.3 & 51.6 \\
\hline
\end{tabular}

\section{Prevalence of Gram-negative rods isolates from bulked milk and smoked containers}

Coliforms are GNR, oxidase negative, and ferment lactose. The predominant coliform genera were Escherichia coli (E. coli) and Enterobacter spp., which accounted for 45.1 and $30 \%$ of the TCC in bulked milk, respectively, and 38.2 and $25.1 \%$ on the smoked milk-handling container surface, respectively (Table 4). The proportion of E. coli and Enterobacter spp. in bulked milk was higher than that on the inner surfaces of milk containers. However, Klebsiella spp. and Salmonella spp. prevalence were higher on smoked milk-handling containers than in bulked milk (Table 4). Studies have shown that the high lysozyme activity in camel milk is effective against Salmonella spp. (el Agamy et al. 1992), thus a probable reason for the low proportion of Salmonella spp. in bulked milk than on smoked milk container surfaces.

The detection of coliforms and E. coli in milk indicates a possible contamination from milk-handling containers (Bonfoh et al. 2003). Coliforms are indicator microorganisms, and the presence of $E$. coli implies a risk of presence of enteric pathogens in milk (Chye et al. 2004). Therefore, the coliforms in bulked milk could be originating from other sources of contamination, such as milk handlers, besides the milk-handling containers. Studies have shown that handling small quantities of milk is subject to a high rate of contamination due to the small ratio of milk volume to container volume (Bonfoh et al. 2003). However, the coliforms in pooled milk being lower than on container surfaces can be explained by the growth of LAB, which produce inhibitory metabolic substances such as lactic and acetic acids, hydrogen peroxide, and bacteriocins (Koutsoumanis et al. 2006). Earlier studies have shown that milk from the camel udder have low microbial load compared to pooled/bulked milk in plastic containers (Matofari et al. 2007; Kaindi et al. 2011). This suggests that milk-handling containers account for the majority of GNR in milk.

\section{The prevalence of $L A B$ isolates from bulked milk and smoked container surfaces}

In this study, the predominant LAB in bulked milk were the Lactobacillus spp. (39.9 \%) and Lactococcus spp. (32.7\%), while the predominant LAB on smoked milkhandling containers were Lactobacillus spp. (36.5 \%) and Lactococcus spp. (29.4 \%) (Table 5). Smoked milkhandling container surfaces were predominated by the Lactobacillus spp. and Lactococcus spp. compared to chlorine-disinfected surfaces, which were predominated by Streptococcus spp. and Lactobacillus spp. The smoked milk containers were found to have higher levels of Leuconostoc spp. (25\%) and Streptococcus spp. (17 \%) than in bulked milk.

The LAB in milk produce lactic acid and other antibacterial substances like bacteriocins that have detrimental effect on other micro-flora in the milk (Tezera and Bruckner 2000). The lactic acid produced lowers the $\mathrm{pH}$ of the milk, inducing the acids to be lipid-soluble and diffuse into the cytoplasm of bacteria through the cell membrane which either inhibit the physiological processes or destroy the bacteria (Gottschalk 1988). Therefore, this can be the cause for the lower TCC in bulked milk than from the smoked containers, and the Klebsiella spp. and Salmonella spp. were the most affected. $\mathrm{LAB}$ are also known to produce bacteriocins and enzymes that can control bio-film formation and growth of spoilage and pathogens (Millette et al. 2006), hence preservation of the milk.

Several studies have reported that the preservation of camel milk is by three different mechanisms. First is the presence of higher levels of the natural antimicrobial compound 'lysozyme' in camel milk than cows' milk (el Agamy et al. 1992). Secondly, the use of wood smoke provides a component of a hurdle system for milk preservation. This is because, among the functional components of smoke, phenols and acids have been shown to have the most antimicrobial activity, while carbonyls and

Table 4 Prevalence of GNR isolates from milk bulked in the smoked containers, smoked container surfaces, and chlorine-disinfected surfaces

\begin{tabular}{lccc}
\hline Genus & Milk bulked in smoked containers & Smoked container surfaces & Chlorine-disinfected container surfaces \\
\hline E. coli spp. (\%) & 45.1 & 38.2 & 47.9 \\
Enterobacter spp. (\%) & 30.0 & 25.1 & 30.0 \\
Klebsiella spp. (\%) & 6.6 & 15.9 & 19.2 \\
Salmonella ssp. (\%) & 18.3 & 20.8 & 2.9 \\
\hline
\end{tabular}


Table 5 Prevalence of LAB isolates from milk bulked in the smoked containers, smoked container surfaces, and chlorine-disinfected surfaces

\begin{tabular}{lccc}
\hline Genus & Milk bulked in smoked containers & Smoked container surfaces & Chlorine-disinfected container surfaces \\
\hline Lactobacillus spp. (\%) & 39.9 & 36.5 & 26.2 \\
Lactococcus spp. (\%) & 32.7 & 29.4 & 21.4 \\
Leuconostoc spp. (\%) & 16.6 & 20.7 & 23.3 \\
Streptococcus spp. (\%) & 10.8 & 23.4 & 29.1 \\
\hline
\end{tabular}

acids have a wide spectrum of antibacterial activity even at low levels of phenols (Toledo 2008). The phenolic acid, acetic acid, and carbonyls individually have antimicrobial activity, but their combined effect is synergistic (Toledo 2007). Thus, a mixture of smoke compounds is an effective antimicrobial agent at a lower level of the components than any of the individual components. Lastly, the LAB have been reported to acquire resistance due to genetic changes resulting from acquisition of plasmids and/or transposon-encoding resistance proteins against the components of smoke in the smoked milk containers, and the LAB also secrete antimicrobial compounds particularly the production of bacteriocins (McDonnell and Russell 1999). These bacteriocins are antimicrobial peptides which produce pores in the cytoplasmic membrane of other spoilage micro-organisms in milk, which inhibits their energy production and biosynthesis activities, thus resulting in the preservation of milk (McIntyre et al. 2007).

\section{Conclusion}

This study has demonstrated that smoking of milkhandling containers is effective in hindering microbial growth and can be used as a technique in the sanitation and preservation of raw camel milk in arid and semiarid areas where cold chains for the preservation of milk are unavailable.

\section{Acknowledgements}

We thank Dr. Muthui of County Livestock Office Isiolo, Kenya, and Mr Abdi Ali and Mr. Khalif Abbey of The Kenya Camel Association for their assistance with field logistics in sample collection. We also thank the RELOAD team members - Mr. Samuel Nato, Mr. Olivier Kashongwe, Miss Linet Mwangi, and Mr. Nicanor Odongo - for their assistance in sample collection and laboratory analysis and for their useful discussions.

\section{Funding}

This study was supported by the funds from Reducing Losses and Adding Value (RELOAD) project funded by the Ministry Education and Research (BMBF), Germany. The funding agency was not involved in collection, analysis, and interpretation of data and in writing the manuscript.

\section{Authors' contributions}

Empirical studies, data collection and analysis, and drafting of the manuscript for this article were conducted by NWW, JWM, and JMN. All authors read and approved the final manuscript.

\section{Authors' information}

All the authors are affiliated to the Department of Dairy and Food Science and Technology, Egerton University. NWW has a diploma in Dairy

Technology and a Bachelor's Degree in Food Science and Technology and is currently undertaking his master's degree at Egerton University. His MSc thesis work explores how milk-handling containers contribute to milk post-harvest losses/contamination among pastoralist communities in Kenya. JWM has a PhD in Food Science (Microbiology) focusing on Food Safety and Biotechnology and has a Master's Degree in Microbiology. JMN has a PhD and Master's Degrees in Biotechnology and Macromolecular Chemistry and a Bachelor's Degree in Food Science and Technology.

\section{Competing interests}

The authors declare that they have no competing interests.

Received: 10 March 2016 Accepted: 27 July 2016

Published online: 31 August 2016

\section{References}

Azadnia, P., and A.H. Khan. 2009. Identification of lactic acid bacteria isolated from traditional drinking yoghurt in tribes of Fars province. Iranian Journal of Veterinary Research, Shiraz University 10(3): S235.

Bloomfield, S.F. 1996. Chlorine and iodine formulations. In Handbook of disinfectants and antiseptics, ed. J.M. Ascenzi, 133-158. New York: Marcel Dekker, Inc.

Bonfoh, B., A. Wasem, A.N. Traore, A. Fane, H. Spillmann, C.F. Simbé, and J. Zinsstag. 2003. Microbiological quality of cows' milk taken at different intervals from the udder to the selling point in Bamako (Mali). Food Control 14(7): 495-500.

Buzby, J.C., and J. Hyman. 2012. Total and per capita value of food loss in the United States. Food Policy 37(5): 561-570.

Chye, F.Y., A. Abdullah, and M.K. Ayob. 2004. Bacteriological quality and safety of raw milk in Malaysia. Food Microbiology 21(5): 535-541.

Coorevits, A., V. De Jonghe, J. Vandroemme, R. Reekmans, J. Heyrman, W. Messens, and M. Heyndrickx. 2008. Comparative analysis of the diversity of aerobic spore-forming bacteria in raw milk from organic and conventional dairy farms. Systematic and Applied Microbiology 31(2): 126-140.

el Agamy, E.I., R. Ruppanner, A. Ismail, C. Champagne, and R. Assaf. 1992. Antibacterial and antiviral activity of camel protective proteins. Journal of Dairy Research 59: 169.

FAO. FAOSTAT database collections. Food and Agriculture Organization of the United Nations. Rome. URL: http://faostat3.fao.org/home/E. Accessed 12 May 2016.

Godefay, B., and B. Molla. 2000. Bacteriological quality of raw milk from four dairy farms and milk collection center in and around Addis Ababa. Berliner und Münchener Tierärztliche Wochenschrift 113: 1-3.

Gottschalk, G. 1988. Bacterial fermentations. In Bacterial metabolism, 2nd ed, 223-224. New York: Springer.

Grainger, J., J. Hurst, and D. Burdass. 2001. Basic practical microbiology: a manual. Reading: The Society for General Microbiology.

Hodges, R.J., J.C. Buzby, and B. Bennett. 2011. Postharvest losses and waste in developed and less developed countries: opportunities to improve resource use. The Journal of Agricultural Science 149: 37-45.

Kaindi, D.W., E. Schelling, J. Wangoh, J.K. Imungi, Z. Farah, and L. Meile. 2011. Microbial quality of raw camel milk across the Kenyan market chain. Global Science Books 1: 79-83.

Koutsoumanis, K.P., I. Geornaras, and J.N. Sofos. 2006. Microbiology of land animals. In Handbook of food science, technology and engineering, vol. 4, ed. Y. H. Hui, 1-52: CRC Press, Taylor and Francis Group.

Lore, T.A., R. Kwirijila, and A. Omore. 2006. Hygienic milk handling: A trading guide for small scale traders in Eastern Africa. Nairobi: ILRI. 
Matofari, J.W., A. Shitandi, P.L. Shalo, N.J. Nanua, and M. Younan. 2007. A survey of Salmonella enterica contamination of camel milk in Kenya. African Journal of Microbiology Research 1(4): 46-50.

McDonnell, G., and D.A. Russell. 1999. Antiseptics and disinfectants: activity, action and resistance. Clinical Microbiology Review 12: 147-179.

Mclntyre, L., J.A. Hudson, C. Billington, and H. Withers. 2007. Biocontrol of foodborne bacteria: Past, present and future strategies, 25-32. New Zealand: The authority of Food Technology, research and manufacturing.

Melesse, K. 2013. Sources of milk products, milk and milk products handling preservation and spices added to the milk products in Ada'a Woreda Ethiopia. International Journal of Agriculture: Research and Review 3(1): 6-12.

Millette, M., Luquet, F.M., and M. Lacroix. 2006. In vitro growth control of selected pathogens by Lactobacillus acidophilus and Lactobacillus casei fermented milk. Letters in Applied Microbiology 44: 314-319.

Mogessie, A., and B. Fekadu. 1993. Effect of container smoking and udder cleaning on microflora and keeping quality of raw milk from a dairy farm in Awassa. Tropical Science 33: 368-378.

Muriuki, H. 2003. Milk and dairy products, post-harvest losses and food safety in sub Saharan Africa and the Near East: A review of the small scale dairy sector in Kenya, FAO Prevention of Food Losses Programme.

Muriuki, H.G. 2011. Dairy development in Kenya. Rome: FAO.

Musinga, M., D. Kimenye, and P. Kivolonzi. 2008. The camel milk industry in Kenya: results of a study commissioned by SNV to explore the potential of camel milk from Isiolo district to access sustainable formal markets. Nanyuki: Report prepared by Resource Mobilisation Centre.

Odongo, N.O., P.O. Lamuka, J.W. Matofari, and G.O. Abong. 2016. Risk factors associated with the post-harvest loss of milk along camel milk value chain in Isiolo County, Kenya. African Journal of Agricultural Research 11(8): 674-682.

Omar, I.A., and M.N. Ahmed. 2012. Effect of adding cardamom, cinnamon and fenugreek to goat's milk curd on the quality of white cheese during storage. International Journal of Dairy Science 7(2): 43-50.

Russell, A.D., and I. Chopra. 1996. Understanding antibacterial action and resistance 2nd ed. London: Ellis Horwood.

Saran, A. 1995. Disinfection in the dairy parlour. Review Scientific Techique International 14: 207-224

SAS Institute Inc. 2006. Base SAS ${ }^{\otimes} .1 .3$ procedures guide, vol. 1, 2, 3 \& 4, 2nd ed. Cary: SAS Institute Inc.

Tezera, G., and H. Bruckner. 2000. Camel milk and meat utilization in Ethiopia, 112-122. Addis Ababa: Proceedings of the 8th National Conference of the Ethiopian Society of Animal Production (ESAP).

Toledo, R.T. 2007. Wood smoke components and functional properties, Smoked seafood safety, 55.

Toledo, R. 2008. Wood smoke components. In International Smoked Seafood Conference Proceedings, ed. D. Kramer and L. Brown, 55-61. Alaska: University of Alaska Fairbanks.

Wayua, F.O., M.W. Okoth, and J. Wangoh. 2012. Survey of postharvest handling, preservation and processing practices along the camel milk chain in Isiolo district, Kenya. African Journal of Food Agriculture Nutrition and Development 12: 7.

Yilma, Z. 2012. Microbial properties of Ethiopian marketed milk and milk products and associated critical points of contamination: An epidemiological perspective. In Epidemiology insights, ed. Lourdes Maria De. Ribeiro De Souza Da Cunha: Tech.

\section{Submit your manuscript to a SpringerOpen ${ }^{\circ}$ journal and benefit from:}

- Convenient online submission

- Rigorous peer review

- Immediate publication on acceptance

- Open access: articles freely available online

- High visibility within the field

- Retaining the copyright to your article

Submit your next manuscript at $>$ springeropen.com 